\title{
Management information systems and their impact on job performance among employees in the private sector: SAUDI Telecommunications companies
}

\author{
Waleed S. Afandi, PhD \\ King Abdulaziz University \\ College of Business Rabigh COB, \\ Head of MIS Department, \\ P. O. Box 344, Rabigh, 21911, \\ Saudi Arabia.
}

\begin{abstract}
This study aimed to identify the (Management information systems and their impact on job performance among employees in the private sector: Telecommunications companies), was conducted this study in the year 2015/2016 $\mathrm{m}$, and chose researcher random sample consisted of 50 workers at the Saudi telecommunications companies, the study concluded that there is a trace of MIS on performance, the study recommended to develop and enact laws and regulations contribute to the effective use of management information systems at the Saudi telecom companies
\end{abstract}

\section{Keywords}

Management information systems, performance, Telecommunications

\section{INTRODUCTION}

The information technology to solve problems through logical thinking, as that information technology is developing understanding and awareness of the many social and economic aspects of Information technology, contribute to the human and cultural development, resource management, and the impact on the social, moral, economic and political relations, and work using information technologies contribute to effective communication and solve problems when they occur and develop work teams and accuracy; it also launches the spirit of creativity and innovation. It also is a main priority for the IT sector to facilitate services and improve productivity and for that integrates range of efforts from employers' organizations and operators of systems and institutions providing hardware and technical regulations, and that the internet has contributed significantly in providing the necessary infrastructure to provide databases. And management information systems linked primarily to information technology, as defined as the structural configuration integrated and interactive of machinery, equipment, software and manpower, which ensures the collection and processing of data in order to provide the necessary information (connected to the beneficiaries, storage, updating and retrieval) the right time, cost and quantity occasions for the internal environment of the organization and the environment Foreign surrounding with respect to its performance in the past, present and possible predictions for the future and as facilitate the task of administrations at all levels in decision-making through the completion of administrative functions and to achieve the best possible use of this information. (Al-Mamary, 2014). There are also a number of requirements for the application of management information systems centered on four basic namely (material requirements, and human, technical and administrative), and prescribed as follows(Laudon \& Jane, 2009):

First: the physical requirements: They represent the physical requirements of devices and networks, and information system, including units of output, input, and central processing units. The physical requirements with other elements help organization in the implementation of business and accounting transactions as well as to assist in the planning and control of production, it also makes it easier for the facility on the regular and special reports, and assist managers in making management decisions and provide the established indicators of the current status and future of work and changes. There is also the role of information technology to analyze problems and make decisions in the industrial and service organizations, the results showed that the use is based on the use of computer information system will help reduce the number of management levels, and increased control in the central decision-making capabilities, and it can strengthen the regulatory decision-making by facilitating communication between the participants in the decision.

Second, the technical requirements: its use of information technology software and techniques lead to visibility problems with a high degree, and the use of information technology in the Saudi insurance sector has increased the efficiency and effectiveness of employees in decisionmaking highly, and that the use of information technology leads to saving time, and information technology a positive role in the effectiveness of the decisions taken. There is also the role of information systems when they are linked to business networks, the level of use of information technology systems, and showed that these systems require advanced use of computer applications, and infrastructure level to upgrade trading within organizations by integrating systems, and the availability of information systems, many solutions can be used in organizations, there are a number of decision-making process it has been developed for use in industrial sectors models.

Third: the requirements of human: there is a role of MIS in the evaluation of staff performance average, the role of management information systems in the training of staff is high developing information systems strategies requires the identification of projects and areas of appropriate information systems, and knowledge of how best to organize the work crew information systems, and information systems and strategic decision-making occur according to the theory 
of the trash, and that he must find mechanisms to prevent individuals from taking decisions related to information systems is linked to the organization and that the trash theory provides strategic decision-making in line with the organization process.

Fourth: Administrative requirements: that the rate of use of management information systems at work was high by administrators. Many studies also showed that there is a relationship between the management information system and the distribution of power between organizational units, as well as the planning and organization of management information and distribution power system activities between the administrative units, and thus the shape that reduces central and helps speed up the decision-making process, and that there is a relationship between the information system administrative and quality of resolution, as well as between the planning, organization and control of management information and the quality of decision-regime activities, and this relationship is the existence of good communication channels between the various organizational units, and thus the speed of access to the necessary information, and then the speed and quality of decision, and the existence of a relationship between the distribution of power between organizational units and the quality of the decision, as well as between concentration and adapt to the uncertainty and the quality of the decision, and there is no relationship between the distribution of power between organizational units and all of reliability, financial resources, and replacement, and there is no relationship between the control of management information and the distribution of power between the organizational units of the system's activities. This, and turn the organization into the use of management information systems course in order to improve the functionality level has, since the improvement of the level of performance is ranked first among the concerns and priorities of the administration in general, where that increase the functional level of performance leads us to improve and raise corporate performance to giving faster service and high quality, and in line with the expectations and needs of the recipient of the service. It is known that the performance level of achievement (in quantity and quality and species), which expresses the extent to which individuals or institutions of their responsibilities and the use of capacity and available resources in the best possible picture. (Joshi, 2013) And expresses performance that enjoyed by workers in the administrative organizations of skills, abilities and potential of communication, if the performance was fit to be accomplished to work, it achieved its purpose, but if the performance does not rise to the level required to complete the work it would require raising the efficiency of workers and improve their performance in order to access to the desired level of performance(Bidgoli, 2004). Through this study, the researcher will identify the theme "Management information systems and their impact on job performance among employees in the private sector: Telecommunications companies" the researcher hopes to tune in putting this issue.

\section{THE PROBLEM STUDY}

The challenges and pressures facing businesses, is growing day after day, and it must bring all that is new in terms of technology in order to be able to cope with its competitors, as it has become urgent to deal with the many challenges of a high degree of seriousness, and positioning themselves to enter the stage coming firmly on the foundations of scientific thought, so you should take advantage of the unfair application of management information with respect to improving the performance, as it is still employ information systems applications without the required level, as the problem of the study by answering questions following the study shows:The first question: Are there differences for the application of management information systems to the telecommunications companies from the viewpoint of its workers due to gender?

Second question: Are there differences for the application of management information systems to the telecommunications companies from the viewpoint of its workers due scientific expertise?

Third question :There are no differences for the application of management information systems to the telecommunications companies from the viewpoint of its workers due to age.

Furth question: Is there an impact on the management information systems of performance from the standpoint of working for the Saudi telecom companies?

\section{HYPOTHESES}

The study relies on assumptions zero following:

1. There are no differences at the level of significance $(\alpha \leq 0.05)$ for the application of management information systems to the telecommunications companies from the viewpoint of its workers due to gender.

2. There are no differences at the level of significance $(\alpha \leq 0.05)$ for the application of management information systems to the telecommunications companies from the viewpoint of its workers due to experience.

3. There are no differences at the level of significance $(\alpha \leq 0.05)$ for the application of management information systems to the telecommunications companies from the viewpoint of its workers due to age.

4. There are no impact at the level of significance ( $\alpha$ $\leq 0.05$ ) on the management information systems of performance from the standpoint of working for the Saudi telecom companies.

\section{OBJECTIVES OF THE STUDY}

Centered primary objective of this study is to identify the " Management information systems and their impact on job performance among employees in the private sector: Telecommunications companies ", as well as can be identified as follows:

- identify the level of application of management information systems to the telecommunications companies from the viewpoint of their employees?

- recognize there are differences for the application of management information systems to the telecommunications companies from the viewpoint of its workers due to gender (male, female)?

- recognize there are differences for the application of management information systems to the telecommunications companies from the viewpoint of its workers due scientific expertise (less than five years, from (5-10) years, more than ten years)?

- recognize there are differences for the application of management information systems to the 
telecommunications companies from the viewpoint of its workers due to age.

- recognize the presence of a trace of MIS on performance from the standpoint of working for the Saudi telecom companies?

\section{IMPORTANCE OF THE STUDY 5.1 Theoretical importance}

The significance of the study by highlighting the theme " Management information systems and their impact on job performance among employees in the private sector: Telecommunications companies ", will also be in this study set of results placed and recommendations contribute to enriching the subject, as he is expected to play this study to identify all obstacles impeding the implementation of management information systems in the Saudi telecommunications companies.

\subsection{Applied Popularity}

It expected to benefit from this study the following categories:

- Working for the Saudi communications companies: they can benefit from this study by identifying the impact of the application of management information systems performance.

- Managers: Can the development of policies and strategies that improve the effective use of management information systems.

- Researchers can see this case study completed; in order to identify the findings, and help them develop in other variables pertaining to the subject of the study.

\section{THE LIMITS OF THE STUDY}

Temporal: This study is based in the year 2015 .

Spatial: The Saudi telecommunications companies.

Human: in order to achieve the purposes and objectives of the study through the distribution of the questionnaire academic tool on a sample of workers in Saudi telecommunications companies.

\section{OPERATIONAL DEFINITIONS OF THE STUDY}

Management information systems: it defined as "a computerized platforms are told that through computers, management and use of the organization, through data analysis and reach rational decisions designed to give the established maximum benefit from the use of computers and the systems to assist in the provision of information, and are analyzed and make the right decisions administratively.

Performance: is defined as the level of achievement and the ability of individuals to act in good possibilities available in an optimal way.

\section{PREVIOUS STUDIES}

Through the following presentation the researcher arranged studies related to the subject of study in descending order:

Study of (Al-Mamary..et..al, 2014) Title is " Factors Affecting Successful Adoption of Management Information Systems in Organizations towards Enhancing Organizational Performance ", this paper investigated management information systems and one of the most important achievements in the field of administrative work, which aims to provide reliable and accurate and relevant information and complete managers towards enhancing organizational performance in organizations. This paper reviews other research in the field of adoption of management information systems in organizations. Synthesis of the literature and interviews with some of the staff of telecommunications companies in Yemen, and this paper proposes a theoretical framework that takes into account the technological and organizational dimensions and people that may affect the adoption of management information systems in organizations. Study (Jane..et..al, 2013) entitled " Management Information System as a Technique in the Administration of Secondary Schools in ABA Zone South East Nigeria", this paper has investigation information management system as a tool in secondary schools in the ABA Education Management District, southeast Nigeria. The descriptive study to determine the extent of the official high school use of management information systems management tool. Has been selected a sample of 44 principals and 210 teachers representing 44 and 10 percent of school principals and teachers of the 100 principles and 2,100 teachers were selected through a stratified random sample representation. A 2-part 0.15 item, used a 4-point Likert scale tool for collecting data to answer questions 2 research and to test the null hypothesis 2 at 00:05 possibility. It has been validated instrument by a team of experts in the Department of Educational Administration, UNIPART, Nigeria, reliability and value of $p=0.85$ is generated. Means was used to answer the research questions. Been applied ttest to test the null hypothesis 2 . The results indicate that the administration results-oriented and quick execution of tasks constitute the general administrative performance of the secondary school principals. He concluded that the proper implementation and application of management information system will be profitable to the administrator, the teacher, the student and the community as a whole. Recommended among others that the government, the Ministry of Education and the Board of Secondary Education schools equipped with the retrieval and dissemination of information storage system. Study of (Navaz, 2013) Title is "Concepts and Applications of Management Information Systems", this study investigate in management Information System (MIS) is an integrated system to provide information to support the planning, organization, control function in this covers the functions of middle management of the administrative and special reports. Management information systems (MIS) are generally automated information that is used within organizations, systems, and includes all the information and communication channels organized. Information system is all items in the collection and dissemination of data and related information, and usually involve changes in the hardware channels, software, people, data, and information and communication. The study showed no differences in terms of gender, age, Operating system, including data collection, data processing and transforming raw data into valuable storage and retrieval of information and data sets, such as administrative reports.

Study (Nayak..et..al, 2012) title of study is " Management Information System for Effective and Efficient Decision Making: A Case Study " , this study investigated the decision-making process is an integral part of the work of any organized part. To facilitate the decision-making process in this world of competition than ever, it is imperative that managers have the right information at the right time to close the gap between the need and expectation. To facilitate a better flow of information management with adequate 
information systems (MIS) is the need of the hour. It is therefore important to have an understanding of management information systems used in the organization by all levels of management in order to make effective decisions. It combines management information system and processes the data (information) and provide them with managers at all levels who use them for decision making, planning and implementation of programs, and control. Information management system has many roles to perform, such as the role of decision support, and the role of monitoring the performance and role of career support. To get a realistic and holistic view of the MIS, it took the management information systems of the Millennium Challenge Corporation Limited (disguised name) as a case study. For a more detailed understanding of a particular function of the company, we studied the need, the uses and benefits of management information systems with regard to the physical department of the company. The inventory management the main focus in our study. MCC Ltd. is one of the first Indian companies to realize the potential and importance of information technology and the adoption of automation and information technology. Computing systems organization began in early 1968. The organization has cut a long way since the days in 1968 when it was used simple machines keypunching. Introduced significant improvements in applications and infrastructure systems. From batch processing systems on the line, from IBM1401 to the latest UNIX-based devices and Windows 2003 it has made it shifts in time determined by the available technologies and work requirements. MIS and facilitated to a large extent, and study result are there are Effective between Management Information system and Decision Making, and synchronize the flow of information in the organization and management feels that it has played a role in the growth and increase the performance of the company.

Study of ( Karim, 2011) Title is " The Significance of Management Information Systems for Enhancing Strategic And Tactical Planning ", this study investigate in management information systems (MIS) is a key factor to facilitate the achievement of the efficiency of decisionmaking in the organization. This paper explores the extent to implement systems to make successful decisions in two of the selected financial organizations and administrative information. Research examined whether the selected financial institutions in Bahrain vary regarding the use of the leadership of management information systems for the purposes of making strategic and tactical planning decision. Conditioning research and quantitative research designed to examine two hypotheses. It was distributed to a total of 190 questionnaires equally to those who work in the various administrative levels in the selected organizations. Search Results showed that the MIS was used primarily to enhance the strategic planning in the financial institutions. Regression analysis revealed that the tactical planning and found to have no effect on the decision-making, while the strategic planning have a clear impact on the effectiveness of decision-making in both organizations and the study showed no differences in terms of gender and experience variable.

Study of ( Reddy..et..al, 2009) Title is " Management Information system to help managers for providing decision making in al organization ", this study investigate in provides management information system (MIS) information on the administrative activities of the organization. The main purpose of this research is, MIS provides accurate and timely information necessary to facilitate decision-making and enable organizations planning and control the executive and the tasks to be carried out effectively process. Management Information System (MIS) is mainly concerned with the processing of data into information and then are transferred to different departments in the organization to take the appropriate decision. MIS is a subset of the overall planning and monitoring, which covers the application of human beings, techniques and procedures of the organization's activities. . Information System is a mechanism to ensure that the information available to managers in the shape you want, and when they need it.

What distinguishes this study from its predecessor (the researcher comment on previous studies):

This study is distinct from previous studies, the following:

- It will unveil workers trends in Saudi telecommunications companies with respect to the subject of the study.

- This study is distinct from previous studies it is descriptive and analytical study, since the researcher will develop a tool to measure represented by the (resolution) as it has been distributed to the employees represented by the sample at the telecommunications companies.

- This is the study of the only studies to examine the subject of the study, so it should shed light on this

\section{THE STUDY PROCEDURES}

\subsection{Study Approach}

It was used descriptive and analytical approach that deals with data collection, analysis and interpretation in addition to the statistical treatment of the variables and their linkages, as well as analysis and interpretation of results by their relevance.

\subsection{The study population and sample}

\begin{tabular}{|c|c|c|}
\hline Age & Frequency & Percentage \\
\hline less than 25 year & 7 & $14.0 \%$ \\
\hline from 25 to 34 year & 6 & $12.0 \%$ \\
\hline from 35 to 44 year & 7 & $14.0 \%$ \\
\hline more than 45 year & 30 & $60.0 \%$ \\
\hline Total & $\mathbf{5 0}$ & $\mathbf{1 0 0 . 0} \%$ \\
\hline
\end{tabular}

The study population consisted of a group of workers at the Saudi telecommunications companies. The study sample consisted of 50 of the workers at the Saudi telecommunications companies, during the year 2015/2016 $\mathrm{m}$; the sample was chosen randomly.

\subsubsection{Gender}

Table (1) Demographic Characteristics of Study Sample (Gender)

\begin{tabular}{|c|c|c|}
\hline Gender & Frequency & Percentage \\
\hline Male & 30 & $60.0 \%$ \\
\hline Female & 20 & $40.0 \%$ \\
\hline Total & $\mathbf{5 0}$ & $\mathbf{1 0 0 . 0} \%$ \\
\hline
\end{tabular}

Table (1) shows that $60.0 \%$ of respondents are males and the rest are females. 


\subsubsection{Experience}

Table (2) Demographic Characteristics of Study Sample (experience)

\begin{tabular}{|c|c|c|}
\hline Experience & Frequency & Percentage \\
\hline less than 5 years & 23 & 46.0 \\
\hline from 5 to 10 years & 12 & 24.0 \\
\hline from 11 to 15 years & 5 & 10.0 \\
\hline 16-20 years & 5 & 10.0 \\
\hline More than 20 years & 5 & 10.0 \\
\hline Total & $\mathbf{5 0}$ & $\mathbf{1 0 0 . 0} \%$ \\
\hline
\end{tabular}

The most percent of experience $(46.0 \%)$ was for respondents whom experience (less than 5 years), as shown in table (4-3) and around $(24.0 \%)$ of respondents have experience (from 5 to 10 years), and $10.0 \%$ are (from 11 to 15 years ), and (16-20 years) are $10.0 \%$, and the rest are (More than 20 years).

\subsubsection{Age}

Table (3) Demographic Characteristics of Study Sample (Age)

\begin{tabular}{|c|c|c|}
\hline Age & Frequency & Percentage \\
\hline less than 25 year & 7 & $14.0 \%$ \\
\hline from 25 to 34 year & 6 & $12.0 \%$ \\
\hline from 35 to 44 year & 7 & $14.0 \%$ \\
\hline more than 45 year & 30 & $60.0 \%$ \\
\hline Total & $\mathbf{5 0}$ & $\mathbf{1 0 0 . 0} \%$ \\
\hline
\end{tabular}

It was found that $(14.0 \%)$ of the sample are (less than 25 year old), (12.0\%) of them are between (25 to 34 years), (14.0\%) of them are (from 35 to 44 year), $(60.0 \%)$ of them are (more than 45 year).

\subsection{The study tool}

In order to obtain information and data; researcher depends on the construction and development of Scale (a questionnaire), a standard tool has been relying on to build reviews and studies and a former literature, and takes into account the build to make effectors conscious of its goal and components, accuracy and clarity and uniformity in the manner that serves the goals and objectives of the study. The way that serves the goals of the study questions.

\subsection{Reliability and validity of the study}

The researcher presented a questionnaire study on a group of university professors, and that they have to amend some paragraphs of the resolution, and the number of paragraphs of the resolution to (19) paragraph. In order to achieve the purposes and objectives of the study questionnaire was designed based on the model Likert (Scale Likert) Quintet, and consisted of two parts, which included the first part on the personal information data, and the second part consisted of paragraphs on the subject of the study, has been grading standard answer for each paragraph in accordance with the Likert scale Quintet and identified five levels: Strongly agree (5 degrees), Agree (4) Neutral (3 degrees) Disagree (degrees) and Strongly Disagree (one degree)
In order to verify the stability of the questionnaire was conducted test (Cronbach's alpha) to measure the stability of the measuring instrument reaching internal consistency of the proportion of the questionnaire $(\alpha=84.4 \%)$ which is an acceptable percentage for the purposes of the study.

Through previous procedures to ensure the veracity of the study tool and determine the sample study, questionnaires were distributed to the sample in question, and then unloaded the study sample on a computer answers, and analyze data using statistical analysis system (Twentieth Edition) (Statistical Package for Social Sciences -SPSS. Ver20).

\subsection{The study variables}

The study variables in management information systems (independent variable), and performance (dependent variable), demographic variables of (gender, experience).

\section{DISCUSS THE RESULTS}

The mean of the scale (3) has been used as a standard for judgment. If the result is lower than (3), this indicates that the phrase was not good. However, if the result is higher than (3) indicating to a good result: The findings and statistical analysis for this part are illustrated in the following table:

\subsection{The First Section : material requirements}

Table (4) shows the mean, standard deviation and the degree of approval for each paragraph on this Field.

Table (4) Means and Standard Deviation of the First Section (material requirements)

\begin{tabular}{|c|c|c|c|}
\hline Questions & Mean & $\begin{array}{c}\text { Std. } \\
\text { Deviation }\end{array}$ & $\mathbf{N}$ \\
\hline \multicolumn{4}{|c|}{ First Section : material requirements } \\
\hline $\begin{array}{l}\text { 1. The Telecommunications } \\
\text { companies develops computer } \\
\text { hardware to keep pace with the } \\
\text { growing demands and needs of } \\
\text { customers. }\end{array}$ & 3.58 & 1.16 & 50 \\
\hline $\begin{array}{l}\text { 2-fit accessory for computer } \\
\text { hardware and nature of the work. }\end{array}$ & 3.33 & 1.26 & 50 \\
\hline $\begin{array}{l}\text { 3-computers used in modern } \\
\text { Telecommunications companies } \\
\text { and high speed. }\end{array}$ & 3.21 & 0.08 & 50 \\
\hline Total & 3.37 & 0.83 & \\
\hline
\end{tabular}

Table number (4) shows that the mean average for the answers about the "First Section: material requirements " (3.37), was "Agree" and the standard deviation was (0.83).

As Shown in Table (4-5), there were positive attitudes toward the above questions because their mean were greater than the mean of the scale (3), but in different percentage.

The phrase which gained the highest mean in this Section is number (2) " The Telecommunications companies develops computer hardware to keep pace with the growing demands and needs of customers ". This means reached (3.58) and the standard deviation was (1.16). 
This means was the lowest and amounted to (3.21) regarding the phrase number (3) " computers used in modern Telecommunications companies and high speed ".

\subsection{The second Section: the Technical Requirements}

Table (5) shows the mean, standard deviation and the degree of approval for each paragraph of this Section.

Table (5) Means and Standard Deviation of Second Section (The Technical Requirements)

\begin{tabular}{|c|c|c|c|}
\hline Questions & Mean & $\begin{array}{c}\text { Std. } \\
\text { Deviation }\end{array}$ & $\mathbf{N}$ \\
\hline \multicolumn{4}{|c|}{ Second Section : The Technical Requirements } \\
\hline 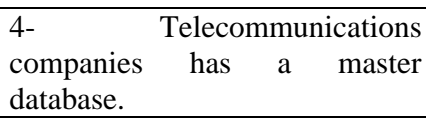 & 3.63 & 1.21 & 50 \\
\hline $\begin{array}{l}\text { 5-latest versions of the software } \\
\text { are available ready-made. }\end{array}$ & 3.42 & 1.11 & 50 \\
\hline $\begin{array}{l}\text { 6-development programs are } \\
\text { automatically and continuously } \\
\text { in collaboration with } \\
\text { programming companies. }\end{array}$ & 3.33 & 1.18 & 50 \\
\hline $\begin{array}{l}\text { 7-available for the latest } \\
\text { versions of operating systems. }\end{array}$ & 3.72 & 1.23 & 50 \\
\hline $\begin{array}{l}\text { 8-software needed by working } \\
\text { constantly to perform } \\
\text { administrative tasks available. }\end{array}$ & 3.26 & 1.11 & 50 \\
\hline $\begin{array}{l}\text { 9-Software security and } \\
\text { protection available on modern } \\
\text { computers. }\end{array}$ & 3.04 & 1.25 & 50 \\
\hline $\begin{array}{l}\text { 10- Telecommunications } \\
\text { companies maintains a presence } \\
\text { backup databases of all } \\
\text { information }\end{array}$ & 3.29 & 0.24 & 50 \\
\hline Total & 3.38 & 1.04 & 50 \\
\hline
\end{tabular}

The previous table shows that the Mean average for the answers of the respondents was about the "second section: The Technical Requirements " (3.38), "Agree" And the average standard deviation was (1.04). As Shown in Table (5), there were positive attitudes toward the above questions because their mean was greater than the mean of the scale (3), but with a different percentage. The phrase which is the high mean in this Section is number (7) "available for the latest versions of operating systems". This means amounted to (3.72) and the average standard deviation was (1.23).

This means gained the lowest level and reached (3.29) in terms of phrase number (10) " Telecommunications companies maintains a presence backup databases of all information ".
10.3 Third Section: human requirements

Table (6) shows the mean, standard deviation and the degree of approval for each paragraph of this section.

Table (6)Means and Standard Deviation of the third section: human requirements

\begin{tabular}{|c|c|c|c|}
\hline Questions & Mean & $\begin{array}{c}\text { Std. } \\
\text { Deviation }\end{array}$ & $\mathbf{N}$ \\
\hline \multicolumn{4}{|c|}{ Third Section : human requirements } \\
\hline $\begin{array}{l}\text { 11-There is a special section in } \\
\text { the Telecommunications } \\
\text { companies for the maintenance } \\
\text { of management information } \\
\text { systems. }\end{array}$ & 3.23 & 1.22 & 50 \\
\hline $\begin{array}{l}\text { 12-There are specialists provide } \\
\text { solutions to the problems of } \\
\text { frequent users. }\end{array}$ & 3.11 & 1.61 & 50 \\
\hline Total & 3.17 & 1.41 & 50 \\
\hline
\end{tabular}

From the above table you can see that the Mean average for the answers of the respondents was about the " Third Section : human requirements " (3.17), "Agree" And the average standard deviation was (1.41). As Shown in Table (6), there were positive attitudes towards the above questions because their mean was greater than the mean of the scale (3), but in different percentage. Phrase number (11) had the highest mean in this Section is number " There is a special section in the Telecommunications companies for the maintenance of management information systems". The average of this means amounted to (3.23) while the standard deviation was (1.22).

The means that had the lowest degrees amounted to (3.11), which relate to the phrase number (12) " There are specialists provide solutions to the problems of frequent users ".

\subsection{Fourth Section: the administrative requirements}

Table (7) shows the mean, standard deviation and the degree of approval for each paragraph of this section.

\begin{tabular}{|c|c|c|c|}
\hline Questions & Mean & $\begin{array}{c}\text { Std. } \\
\text { Deviation }\end{array}$ & $\mathbf{N}$ \\
\hline \multicolumn{4}{|c|}{ Fourth Section : the administrative requirements } \\
\hline $\begin{array}{l}\text { 13-availability of management } \\
\text { information systems all the } \\
\text { information needed by the } \\
\text { workers in the various sections } \\
\text { of Telecommunications } \\
\text { companies. }\end{array}$ & 3.53 & 1.19 & 50 \\
\hline $\begin{array}{l}\text { 14-availability of management } \\
\text { information systems all the } \\
\text { information to employees in a } \\
\text { timely manner. }\end{array}$ & 3.42 & 1.22 & 50 \\
\hline $\begin{array}{l}15 \text {-information is updated } \\
\text { constantly to suit the needs of } \\
\text { workers. }\end{array}$ & 3.24 & 1.23 & 50 \\
\hline Total & 3.39 & 1.21 & 50 \\
\hline
\end{tabular}

The previous table shows that the Mean average for the answers of the respondents was about the "fourth section: the 
administrative requirements " (3.39), "Agree" And the average standard deviation was (1.21)

The phrase which is the high mean in this Field is number (13) which said (availability of management information systems all the information needed by the workers in the various sections of Telecommunications companies), whereas the mean was (3.53) and the average standard deviation was (1.19).

This means was the lowest and reached (3.24) to the phrase number (15) which said (information is updated constantly to suit the needs of workers).

\subsection{Fifth Section: performance}

Table (8) shows the mean, standard deviation and the degree of approval on each paragraph.

Table (8) Means and Standard Deviation of the Fifth Section: " performance "

\begin{tabular}{|c|c|c|c|}
\hline Questions & Mean & $\begin{array}{c}\text { Std. } \\
\text { Deviation }\end{array}$ & $\mathbf{N}$ \\
\hline \multicolumn{4}{|c|}{ Fifth Field: performance } \\
\hline $\begin{array}{l}\text { 16-management information } \\
\text { system reduces the number of } \\
\text { employees. }\end{array}$ & 3.64 & 1.31 & 50 \\
\hline $\begin{array}{l}\text { 17-management information } \\
\text { system provides a lot of time. }\end{array}$ & 3.45 & 1.25 & 50 \\
\hline $\begin{array}{l}\text { 18-provides } \\
\text { information system to reduce } \\
\text { waste of resources }\end{array}$ & 3.52 & 1.19 & 50 \\
\hline $\begin{array}{l}\text { 19-help management information } \\
\text { systems to improve the services } \\
\text { provided to the organization } \\
\text { clients. }\end{array}$ & 3.51 & 1.25 & 50 \\
\hline Total & 3.53 & 1.25 & 50 \\
\hline
\end{tabular}

The previous table shows that the Mean average for the answers of the respondents was regarding the " Fifth Section: " performance " (3.58), "Agree" and the average standard deviation was (1.25).

The phrase which is the high mean in this Field is number (16) which said (management information system reduces the number of employees). Whereas its means was reached (3.64) and the average standard deviation was (1.131).

This indicates that the lowest results reached (3.45) to phrase number (17) " management information system provides a lot of time ".

\section{TESTING OF THE HYPOTHESIS}

This study is based on two hypotheses namely: the null and the sub-set assumptions, which are:

\section{First hypothesis :}

H01: There are no differences at the level of significance $(\alpha$ $\leq 0.05)$ for the application of management information systems to the telecommunications companies from the viewpoint of its workers due to gender.
In order to validate the hypothesis (first sub-hypothesis) test was performed (Independent Samples T-Test), the table (9), show that.

Table (9) Test of hypothesis (first hypothesis)(Independent Samples T-Test)

\begin{tabular}{|c|c|c|c|c|c|c|}
\hline Section & $\begin{array}{c}\text { Me } \\
\text { an } \\
(\mathbf{m a} \\
\text { le) }\end{array}$ & $\begin{array}{c}\text { Male } \\
\text { Stand } \\
\text { ard } \\
\text { Deviat } \\
\text { ions }\end{array}$ & $\begin{array}{c}\text { Mean } \\
\text { (Fem } \\
\text { ale) }\end{array}$ & $\begin{array}{c}\text { Male } \\
\text { Stand } \\
\text { ard } \\
\text { Deviat } \\
\text { ions }\end{array}$ & $\begin{array}{l}\text { Val } \\
\text { ue } \\
(\mathbf{t})\end{array}$ & $\begin{array}{l}\text { SI } \\
\text { G }\end{array}$ \\
\hline $\begin{array}{l}\text { First } \\
\text { Section : } \\
\text { material } \\
\text { requirem } \\
\text { ents }\end{array}$ & $\begin{array}{c}3.62 \\
59\end{array}$ & .9725 & $\begin{array}{c}3.776 \\
5\end{array}$ & .9971 & $\begin{array}{r}- \\
1.1 \\
27\end{array}$ & $\begin{array}{l}.5 \\
26\end{array}$ \\
\hline $\begin{array}{l}\text { Second } \\
\text { Section : } \\
\text { The } \\
\text { Technica } \\
\text { I } \\
\text { Require } \\
\text { ments }\end{array}$ & $\begin{array}{c}3.53 \\
45\end{array}$ & 1.0235 & $\begin{array}{c}3.411 \\
8\end{array}$ & 1.0390 & $\begin{array}{r}.87 \\
7\end{array}$ & $\begin{array}{l}.7 \\
26\end{array}$ \\
\hline $\begin{array}{l}\text { Third } \\
\text { Section : } \\
\text { human } \\
\text { requirem } \\
\text { ents }\end{array}$ & $\begin{array}{c}3.74 \\
66\end{array}$ & 1.0548 & $\begin{array}{c}3.570 \\
6\end{array}$ & 1.0836 & $\begin{array}{r}1.2 \\
13\end{array}$ & $\begin{array}{l}.7 \\
49\end{array}$ \\
\hline $\begin{array}{l}\text { Fourth } \\
\text { Section : } \\
\text { the } \\
\text { administ } \\
\text { rative } \\
\text { requirem } \\
\text { ents }\end{array}$ & $\begin{array}{c}3.61 \\
49\end{array}$ & 1.0769 & $\begin{array}{c}3.478 \\
8\end{array}$ & 1.1245 & $\begin{array}{r}.91 \\
3\end{array}$ & $\begin{array}{l}.7 \\
04\end{array}$ \\
\hline
\end{tabular}

Table (9) shows that there are no significant statistical differences at $(\alpha \leq 0.05)$ level between for the application of management information systems to the telecommunications companies from the viewpoint of its workers depending on the demographic variables (gender).

\section{Second: hypothesis}

H02: There are no differences at the level of significance ( $\alpha \leq$ $0.05)$ for the application of management information systems to the telecommunications companies from the viewpoint of its workers due to experience.

In order to validate the second hypothesis a test was performed (One Way ANOVA), the table (10), shows that result.

Table (10) Test of hypothesis (Second sub-hypothesis) (One Way ANOVA)

\begin{tabular}{|c|c|c|c|c|c|c|}
\hline Section & Items & $\begin{array}{c}\text { Sum } \\
\text { of } \\
\text { Squa } \\
\text { res }\end{array}$ & $\begin{array}{c}\text { Mea } \\
\text { n } \\
\text { Squa } \\
\text { re }\end{array}$ & $\mathbf{F}$ & d & Sig. \\
\hline \multirow{2}{*}{$\begin{array}{l}\text { First } \\
\text { Section : } \\
\text { material } \\
\text { requireme } \\
\text { nts }\end{array}$} & $\begin{array}{l}\text { Betwe } \\
\text { en } \\
\text { Group } \\
\mathrm{s}\end{array}$ & $\begin{array}{c}13.28 \\
4\end{array}$ & 4.428 & $\begin{array}{l}4.8 \\
07\end{array}$ & $\begin{array}{l}4 \\
7\end{array}$ & $\begin{array}{c}.75 \\
8\end{array}$ \\
\hline & $\begin{array}{l}\text { Withi } \\
\mathrm{n} \\
\text { Group } \\
\mathrm{s}\end{array}$ & $\begin{array}{c}197.1 \\
33\end{array}$ & .921 & & 2 & \\
\hline
\end{tabular}




\begin{tabular}{|c|c|c|c|c|c|c|}
\hline & Total & $\begin{array}{c}210.4 \\
17\end{array}$ & & & $\begin{array}{l}4 \\
9 \\
\end{array}$ & \\
\hline \multirow{3}{*}{$\begin{array}{l}\text { Second } \\
\text { Section : } \\
\text { The } \\
\text { Technical } \\
\text { Requirem } \\
\text { ents }\end{array}$} & $\begin{array}{l}\text { Betwe } \\
\text { en } \\
\text { Group } \\
\text { s }\end{array}$ & $\begin{array}{c}20.23 \\
6\end{array}$ & 6.745 & $\begin{array}{l}6.8 \\
71\end{array}$ & $\begin{array}{l}4 \\
7\end{array}$ & $\begin{array}{l}0.8 \\
72\end{array}$ \\
\hline & $\begin{array}{l}\text { Withi } \\
\mathrm{n} \\
\text { Group } \\
\mathrm{s}\end{array}$ & $\begin{array}{c}210.0 \\
70\end{array}$ & .982 & & 2 & \\
\hline & Total & $\begin{array}{c}230.3 \\
05\end{array}$ & & & $\begin{array}{l}4 \\
9\end{array}$ & \\
\hline \multirow{3}{*}{$\begin{array}{l}\text { Third } \\
\text { Section : } \\
\text { human } \\
\text { requireme } \\
\text { nts }\end{array}$} & $\begin{array}{l}\text { Betwe } \\
\text { en } \\
\text { Group } \\
\text { s }\end{array}$ & $\begin{array}{c}19.03 \\
7\end{array}$ & 6.346 & $\begin{array}{l}5.9 \\
25\end{array}$ & $\begin{array}{l}4 \\
7\end{array}$ & $\begin{array}{l}0.5 \\
24\end{array}$ \\
\hline & $\begin{array}{l}\text { Withi } \\
\mathrm{n} \\
\text { Group } \\
\mathrm{s}\end{array}$ & $\begin{array}{c}229.1 \\
84\end{array}$ & 1.071 & & 2 & \\
\hline & Total & $\begin{array}{c}248.2 \\
21\end{array}$ & & & $\begin{array}{l}4 \\
9 \\
\end{array}$ & \\
\hline \multirow{3}{*}{$\begin{array}{l}\text { Fourth } \\
\text { Section : } \\
\text { the } \\
\text { administr } \\
\text { ative } \\
\text { requireme } \\
\text { nts }\end{array}$} & $\begin{array}{l}\text { Betwe } \\
\text { en } \\
\text { Group } \\
\text { s }\end{array}$ & $\begin{array}{c}29.64 \\
1\end{array}$ & 9.880 & $\begin{array}{l}9.0 \\
97\end{array}$ & $\begin{array}{l}4 \\
7\end{array}$ & $\begin{array}{l}0.2 \\
45\end{array}$ \\
\hline & $\begin{array}{l}\text { Withi } \\
\mathrm{n} \\
\text { Group } \\
\mathrm{s}\end{array}$ & $\begin{array}{c}232.4 \\
26\end{array}$ & 1.086 & & 2 & \\
\hline & Total & $\begin{array}{c}262.0 \\
67\end{array}$ & & & $\begin{array}{l}4 \\
9\end{array}$ & \\
\hline
\end{tabular}

* significant at the level $(\alpha \leq 0.05)$

Table (10) shows that there are significant statistical differences at the level of significance $(\alpha \leq 0.05)$ for the application of management information systems to the telecommunications companies from the viewpoint of its workers due to experience

\section{Third: hypothesis}

H03: There are no differences at the level of significance $(\alpha$ $\leq 0.05$ ) for the application of management information systems to the telecommunications companies from the viewpoint of its workers due to age.

In order to validate the hypothesis (Third hypothesis) test was performed (One Way ANOVA), the table (11), shows that result.

Table (11) Test of hypothesis (Third hypothesis) (One Way ANOVA)

\begin{tabular}{|c|c|c|c|c|c|c|}
\hline Section & Items & $\begin{array}{l}\text { Sum of } \\
\text { Squar } \\
\text { es }\end{array}$ & $\begin{array}{c}\text { Mean } \\
\text { Squar } \\
\text { e }\end{array}$ & $\mathbf{F}$ & $\begin{array}{l}d \\
\text { f }\end{array}$ & Sig. \\
\hline \multirow{3}{*}{$\begin{array}{l}\text { First Section } \\
: \quad \text { material } \\
\text { requirement } \\
\text { s }\end{array}$} & $\begin{array}{l}\text { Betwee } \\
\text { n } \\
\text { Groups }\end{array}$ & 22.065 & 7.355 & 8.356 & $\begin{array}{l}4 \\
7\end{array}$ & .744 \\
\hline & $\begin{array}{l}\text { Within } \\
\text { Groups }\end{array}$ & $\begin{array}{r}188.35 \\
2 \\
\end{array}$ & .880 & & 2 & \\
\hline & Total & $\begin{array}{r}210.41 \\
7\end{array}$ & & & $\begin{array}{l}4 \\
9\end{array}$ & \\
\hline \multirow{2}{*}{$\begin{array}{l}\text { Second } \\
\text { Section : } \\
\text { The } \\
\text { Technical }\end{array}$} & $\begin{array}{l}\text { Betwee } \\
\mathrm{n} \\
\text { Groups }\end{array}$ & 31.581 & $\begin{array}{r}10.52 \\
7\end{array}$ & $\begin{array}{r}11.33 \\
6\end{array}$ & $\begin{array}{l}4 \\
7\end{array}$ & $\begin{array}{c}0.84 \\
1\end{array}$ \\
\hline & Within & 198.72 & .929 & & 2 & \\
\hline
\end{tabular}

\begin{tabular}{|c|c|c|c|c|c|c|}
\hline \multirow{2}{*}{$\begin{array}{l}\text { Requiremen } \\
\text { ts }\end{array}$} & Groups & 4 & & & & \\
\hline & Total & $\begin{array}{r}230.30 \\
5\end{array}$ & & & $\begin{array}{l}4 \\
9\end{array}$ & \\
\hline \multirow{3}{*}{$\begin{array}{l}\text { Third } \\
\text { Section : } \\
\text { human } \\
\text { requirement } \\
\text { s }\end{array}$} & $\begin{array}{l}\text { Betwee } \\
\mathrm{n} \\
\text { Groups }\end{array}$ & 31.347 & $\begin{array}{r}10.44 \\
9\end{array}$ & $\begin{array}{r}10.31 \\
0\end{array}$ & $\begin{array}{l}4 \\
7\end{array}$ & $\begin{array}{c}0.11 \\
4\end{array}$ \\
\hline & $\begin{array}{l}\text { Within } \\
\text { Groups }\end{array}$ & $\begin{array}{r}216.87 \\
4 \\
\end{array}$ & 1.013 & & 2 & \\
\hline & Total & $\begin{array}{r}248.22 \\
1\end{array}$ & & & $\begin{array}{l}4 \\
9\end{array}$ & \\
\hline \multirow{3}{*}{$\begin{array}{l}\text { Fourth } \\
\text { Section } \\
\text { the } \\
\text { administrati } \\
\text { ve } \\
\text { requirement } \\
\text { s }\end{array}$} & $\begin{array}{l}\text { Betwee } \\
n \\
\text { Groups }\end{array}$ & 36.836 & $\begin{array}{r}12.27 \\
9\end{array}$ & $\begin{array}{r}11.66 \\
6\end{array}$ & $\begin{array}{l}4 \\
7\end{array}$ & $\begin{array}{c}0.22 \\
2\end{array}$ \\
\hline & $\begin{array}{l}\text { Within } \\
\text { Groups }\end{array}$ & $\begin{array}{r}225.23 \\
1\end{array}$ & 1.052 & & 2 & \\
\hline & Total & $\begin{array}{r}262.06 \\
7\end{array}$ & & & $\begin{array}{l}4 \\
9\end{array}$ & \\
\hline
\end{tabular}

* significant at the level $(\alpha \leq 0.05)$

\section{Fourth: hypothesis:}

H04: There are no impact at the level of significance $(\alpha \leq$ 0.05 ) on the management information systems of performance from the standpoint of working for the Suadi telecom companies.

In order to validate the hypothesis (fourth hypothesis) test was performed (Standard Multiple Regression Analysis).

Table (12)Test of hypothesis (fourth hypothesis )(Standard Multiple Regression Analysis)

\begin{tabular}{|c||c||c||c||c||c|}
\hline Beta & $\begin{array}{c}\mathbf{F} \\
\text { Tabulated }\end{array}$ & $\mathbf{R}^{2}$ & $\mathbf{R}$ & Sig & $\begin{array}{c}\text { Result } \\
\text { of Ho }\end{array}$ \\
\hline \hline 0.824 & 628.781 & 0.677 & 0.824 & 0.000 & Reject \\
\hline
\end{tabular}

Show data table (16) that the level of significance $(0.000)$ which is less than (0.05), and thus have a decision rule says accept the alternative hypothesis, if the level of significance (SIG) greater than (0.05), and we reject the hypothesis nihilism if the significance level less from (0.05), and through the previous table shows that the level of significance (SIG) is equal to (0.000), and since this level of significance is less than the level of (0.05) decision rule that " there are impact at the level of significance $(\alpha \leq 0.05)$ on the management information systems of performance from the standpoint of working for the Saudi danian telecom companies".

\section{FINDINGS AND \\ RECOMMENDATIONS}

Will be through the following display the most beautiful of the outcome of their findings: First results of the study: can summarize the results of the study, by answering the questions of the study:

\subsection{Findings}

The first question: Are there differences for the application of management information systems to the telecommunications companies from the viewpoint of its workers due to gender (male, female)? (It represents the answer to the first hypothesis)

Found through statistical analysis that: " there are no significant statistical differences at $(\alpha \leq 0.05)$ level between for the application of management information systems to the telecommunications companies from the viewpoint of its 
workers depending on the demographic variables (gender) ", This result is similar to a study (Navaz, 2013) and (Karim,2011), it showed no differences in terms of gender.

Second question: Are there differences for the application of management information systems to the telecommunications companies from the viewpoint of its workers due scientific expertise (less than five years, from (5-10) years, more than ten years)?(Represents the answer to the second hypothesis)

Found through statistical analysis that: " that there are significant statistical differences at the level of significance $(\alpha \leq 0.05)$ for the application of management information systems to the telecommunications companies from the viewpoint of its workers due to experience ", this result is similar to a study (Karim, 2011) it showed no differences in terms of gender, age and experience variable.

Third question :There are no differences for the application of management information systems to the telecommunications companies from the viewpoint of its workers due to age. (Represents the answer to the third hypothesis)

Found through statistical analysis that: " there are significant statistical differences at $\quad(\alpha \leq 0.05)$ for the application of management information systems to the telecommunications companies from the viewpoint of its workers due to age ", this result is similar to a study (Navaz, 2013) it showed no differences in terms of age variable.

Fourth question: Is there an impact on the management information systems of performance from the standpoint of working for the Saudi telecom companies? (Represents the answer to the fourth hypothesis)

Found through statistical analysis that: " there are impact at the level of significance $(\alpha \leq 0.05)$ on the management information systems of performance from the standpoint of working for the Saudi telecom companies " This result is similar to a study (Nayak..et..al, 2012) it showed that there are Effective between Management Information system and Decision Making.

\subsection{The recommendations of the study}

In light of the above findings, the study recommend the following:

1. Put the enactment of laws and regulations contribute to the effective use of management information systems at the Saudi telecommunications companies.

2. Develop programs and training courses contribute to improving the skills of workers in Saudi telecommunications companies in terms of management information systems.
3. Recruitment of management information systems in order to improve performance at work. 4 . involvement of experienced and competent with respect to the use of management information systems.

4. The need for new research in the field of study conduct.

5. Disseminate the results of the study on the relevant sectors.

\section{REFERENCES}

[1] Al-Mamary, Y. H. , Shamsuddin, A. , \& Aziati, N. (2014). Factors Affecting Successful Adoption of Management Information Systems in Organizations towards Enhancing Organizational Performance. American Journal of Systems and Software, 2(5), 121-126.

[2] Bidgoli, Hossein, (2004). The Internet Encyclopedia, Volume 1, John Wiley \& Sons, Inc .

[3] Jane, N. Uchenna, Ememe O, Nwuju, O, Comfort, N, (2013), Management Information System as a Technique in the Administration of Secondary Schools in ABA Zone South East Nigeria, International Journal of Learning and Development, 3(3): 15-42.

[4] Joshi, Girdhar (2013). Management Information Systems. New Delhi Delhi: Oxford University Press.

[5] Karim, Akram (2011), The Significance of Management Information Systems for Enhancing Strategic And Tactical Planning, Journal of Information Systems and Technology Management, 8 (2): 459-470.

[6] Laudon, Kenneth C. Jane P., (2009). Management Information Systems: Managing the Digital Firm (11 ed.). Prentice Hall/CourseSmar

[7] Navaz, V., (2013), Concepts and Applications of Management Information, Arabian Journal of Business and Management Review, 2 (6):6-15.

[8] Nayak, Gautham and Sequeira, A. H. and Senapati, Sanjay, (2012),Management Information System for Effective and Efficient Decision Making: A Case Study available-at

SSRN:http://ssrn.com/abstract=2174035 or http://dx.doi .org/10.2139/ssrn.2174035

[9] Reddy, g, Srinivasu, R, Rikki, S, Rao, V,. (2009), Management Information system to help managers for providing decision making in al organization , International Journal of Reviews in Computing, 5(9): 2076-3336. 